\title{
The Evaluation of the Degree of Applying Risk Management Behaviors among Sports Councils in East of Iran
}

\author{
Mohammad Ehsani ${ }^{1}$ \& Korosh Veisi ${ }^{2}$ \\ ${ }^{1}$ Tarbiat Modares University, Tehran, Iran \\ ${ }^{2}$ Department of Sport Management, Science and Research Branch, Islamic Azad University, Kurdistan, Iran \\ Correspondence: Mohammad Ehsani, Tarbiat Modares University, Tehran, Iran. Tel: 98-21-8288-3178. E-mail: \\ Ehsani@modares.ac.ir
}

Received: January 28, 2012

Accepted: April 19, 2012

Published: August 1, 2012

doi:10.5539/ass.v8n10p240

URL: http://dx.doi.org/10.5539/ass.v8n10p240

\begin{abstract}
The aim of this study is to determine the degree of applying risk management behaviors among managers and directors of sports councils in Khorasan province which is located in the east of Iran. The method was descriptive-analytic, and conducted on all the managers and directors of sports councils. The samples was included 126 managers and directors of sports councils in Khorasan who had been working in the East area (Khorasan). The questionnaire (risk management, Aeron. 2004) was used and Cronbach Alpha was .87 which was satisfactory. Descriptive and inferential statistics (Kruskal Wallis H, Kendall \& Pearson), have been used in data analysis. The findings of the research showed that there isn't any meaningful relationship between levels of education, the employment status, coaching status and risk management behaviors, while there was meaningful relationship between field of education $(\mathrm{p} \leq 0.006)$, coaching experience $(\mathrm{p} \leq 0.033, \mathrm{r}=0.185)$, managing experience $(\mathrm{p} \leq 0.001, \mathrm{r}=0.260)$ and risk management behaviors. As a whole we can say that the level of performance of risk management behaviors among the sports councils in Kuhorsan province has a desirable condition. It was also found that staff directors performed risk management behaviors better than line directors.
\end{abstract}

Keywords: risk management behaviors, supervision, medical concerns, sports councils

\section{Introduction}

Psychologists and sociologists consider sport as a social and cultural phenomenon which is inseparable with other social structures. There have always been risks around sport and athletics as other social phenomena which can cause problems to the whole society. Destroying and damaging the sport complexes and places has to do with the very basic social factors such as economic, politics and culture. A good relation between these basic facts can lead to have a better and safer athletic environment (Lhotsky, 2006). Nowadays there are a lot of arguments on this subject around the world, and scientists are seriously making research to find and introduce new techniques making athletic atmosphere safer and controllable than ever for reducing, transferring and eliminating risks (Dusti, 2009). Human beings have been trying to discover new and effective ways to protect themselves from surrounding dangers. To protect you against a dangerous situation is a question of how considering 'risk'. Mass Media are talking about different incidents, disasters and natural forces all over the world. We all look for ways to prevent such disasters (Setrorg Dorre Shuri \& Dalvi Esfahani, 2005).

Risk Management is supposed to estimate the amount of loss and dangers threatening the sports organizations and councils. It is also expected to present practical techniques against potential dangers. The main goal of this system is to make a safe and comfortable atmosphere for both players and spectators in sport complexes (Veisi et al, 2010; Aaron, 2004 \& Anderson, 1994). In other words the objective of risk management strategies is to be well-prepared before something happens (Setrorg Dorre Shuri \& Dalvi Esfahani, 2005). To rich this goal we need to create a big and perfect program. Risk management is not just to think about the financial matters but the health of athletics and spectators. Another reason which makes the risk management is the moral responsibility and regulatory aspect of saving the social environment safe and pleasant (Hronek and Spengler, 2002; Stacey, 2006). The increasing number of litigation and the big portion of money spending on this way made sports managers and directors to think up with a new idea solving this problem called 'risk management'(Clement, 1998; Kavaler and Spiegel, 1997). Some researchers have shown that there is no meaningful difference between 
identifying and controlling the risks and managing the swimming pools (private and public), but there are differences between evaluating the degree of the risk and managing them. And between genders, experience and risk management, litigation and the happenings was also found significant correlation. In addition to these, significant correlations have been shown between swimming pools and risk management. At the end there is a significant relation between risk management, litigation and percentage of happenings (Izadi, 2009).

Some other researchers pointed out the local government's recipes for risk management are not compatible about stadiums, directors and events management, and there is no one as the managers of risk management council in the stadiums. And there was no action taken in order to organize the sale of tickets at the stadiums. Among all stadiums, Azadi Stadium (it is main stadium in Iran) is the best one in which the risk management strategies are adapted (Rahimi et al, 2002). Many studies proved that $75 \%$ of heads and leaders of sports departments in Tehran doesn't know about risk management which results in such problems in stadiums (Dusti, 2009).

The bad condition of soccer stadiums in Iran and their substandard designs can be the most important cause of the spectators' dissatisfaction. Some spectators believed that unfair behavior among players and referees' decisions is the main reason for such risks. Players themselves accused the press and media and believed that they rouse such problems in the stadiums (Dusti, 2009). Another research showed that $71 \%$ of the stadiums are not performing risk management strategies and $51 \%$ of them do not have safety committee (Mulroney and Ammon, 1995; Pantera, 1993). According to Sawyer, 2002. directors of sports department rarely perform risk management techniques (Likert 5 grade Scale).

The research on the athletic high schools in Florida showed that risk management strategies are more useful for those schools. It considered the good performance of the coaches and level of coaching is the most important factor in succeeding in utilizing the risk management principles (Aeron, 2004). In the same route, another research says the knowledge level of coaches about risk management, age of coaches and players, health and safety programs of the organizations; first aid training etc are the most important factors which should be considered in risk management (Lachapelle, 2004). Another article on the NCAA (National Collegiate Athletic Association) showed that the capacity of the stadiums is the most important factor in risk management. According to this survey risk management strategies are mostly used in large stadiums than the small ones. It also mentioned that most managers who educated in sports, are young (Lhotsky, 2006).

There are many studies on this subject, which shows the importance of risk management and using it in sports affairs. It is considered a new branch of management which is surrounded by many articles and researches which make it hard to find any organizations in modern world which not applied risk management techniques (Arthur Williams and Richard Dam, 1924; Brown \& Sawyer, 1998). Unfortunately studies in Iran's sport council and the management of the stadiums showed that the administrators had no knowledge of risk management. After half of a century publishing and researching on this subject, there are still not enough investigations in this field in Iran. So, it is normal that there would be no attention for it in the planning of the sports organizations (Veisi et al, 2010).

Because of lack of studies the researchers started to study the degree of applying risk management behaviors in sports departments and councils of Khorasan province.

\section{Methodology}

The method of the study is descriptive-analytic, and it was asked by all the managers and directors of sports councils. The samples included 126 heads and directors of sports councils in Khorasan who have been selected all as a research samples. This selection was according to their tangible role in the sports affaire of the province. To evaluate the applying of risk management behaviors we used Thomas C, Aeron Questionnaire (Supervision, medical Service, facility, equipment, security \& spectators controlling, transportation, security of equipment). In order to determine the validity and stability of the questionnaires, identifying and removing the probable ambiguities, an initial study conducted on 30 of managers and experts in physical education colleges in Iranian Universities. To determine face and content validity, it was used expert's opinions; to determine constituent validity, we used factor analysis. The amount of factor analysis for risk management scale was $(\mathrm{AGFI}=53, \mathrm{df}=$ 000, $\mathrm{P}=0.944$ ).

Also to determine the stability, Cronbach's alpha for risk management questionnaire was $\alpha=0.87$. which was satisfactory. And the instrument had a good internal validity. In order to orange and summarize the data, we used descriptive statistics; in inferential statistics we used factor analysis (constituent validity survey; Kruskal Wallis H, Kendal Correlation and Spearman). It was analyzed through Lisrel Software 8.5. Version and SPSS/16. The reason for selecting non-parametric test was the meaningfulness founded in Kolmogrof-Smirnov Test $(\mathrm{z}=3.068$ and $\operatorname{sig}=0.001$ ). 
Research has shown that the sport managers of Khorasan got 4 out of 5 scores, which means they try to perform risk management behaviors most of the time. As it can be seen in Figure 1, it is also proved that there is a significant relationship between the coaching experience, management skill and risk management behaviors. It demonstrates the degree of utilization of risk management behavior by managers and directors of sport departments in Khorasan (Table 1).

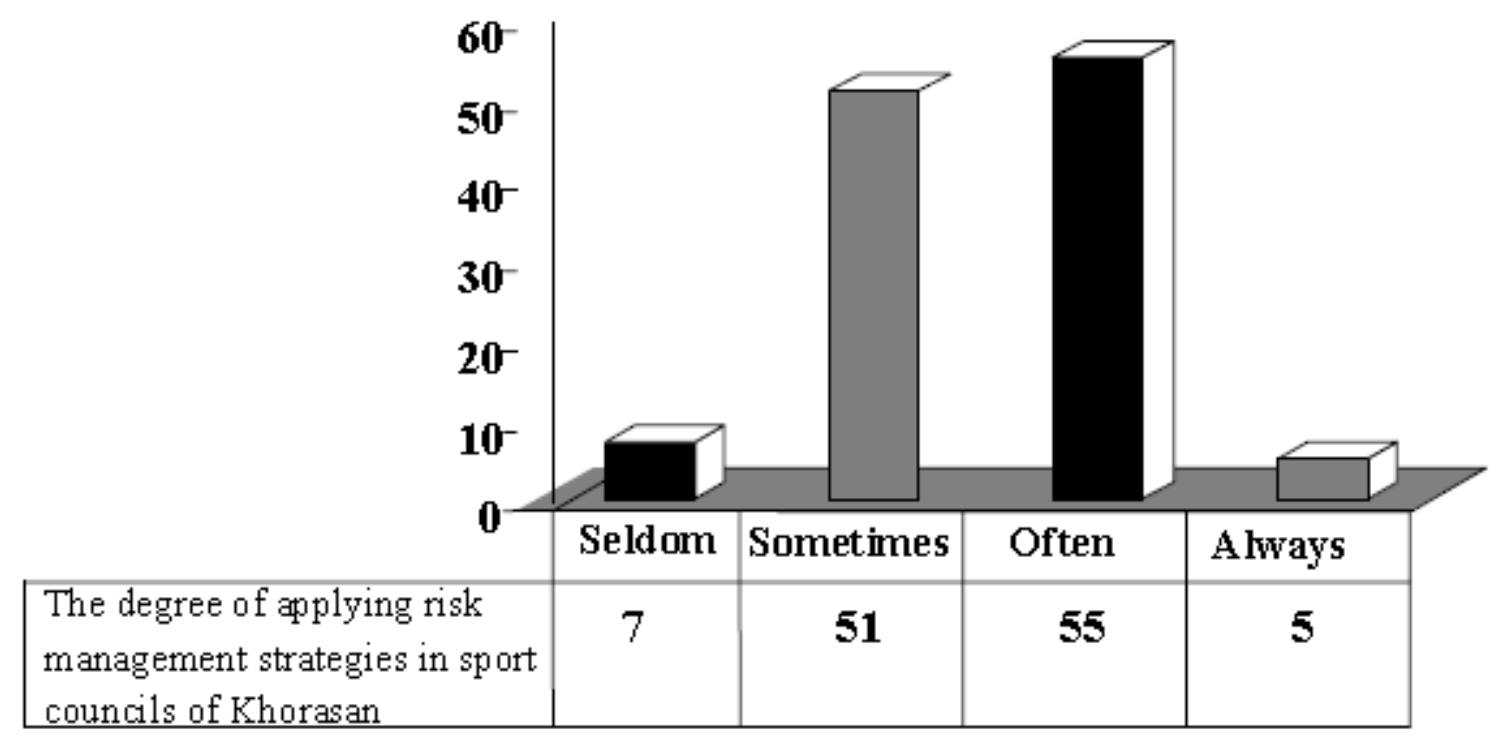

Figure 1. The degree of applying risk management strategies in sport councils of Khorasan

Table 1. Descriptive analysis about heads and directors of sport councils in Khorasan Province

\begin{tabular}{|c|c|c|c|c|c|c|c|c|c|}
\hline \multirow{2}{*}{$\begin{array}{c}\text { Sample Survey } \\
\text { Council }\end{array}$} & \multicolumn{3}{|c|}{ Gender } & \multicolumn{3}{|c|}{ Educational Degree } & \multicolumn{3}{|c|}{ Major } \\
\hline & gender & Num & $\%$ & Degree & Num & $\%$ & Educated & Nun & $\%$ \\
\hline \multirow{5}{*}{$\begin{array}{c}\text { Sports councils of } \\
\text { Khorasan }\end{array}$} & \multirow{3}{*}{ Female } & \multirow{3}{*}{42} & \multirow{3}{*}{$29 / 7$} & Diploma & 24 & 20.3 & & & \\
\hline & & & & A.D. & 12 & 10.20 & $\begin{array}{l}\text { Physical } \\
\text { Education }\end{array}$ & 39 & 33.1 \\
\hline & & & & Bachelor & 70 & 59.30 & $\begin{array}{l}\text { Other } \\
\text { Majors }\end{array}$ & 69 & 58.5 \\
\hline & \multirow{2}{*}{ Male } & \multirow{2}{*}{84} & \multirow{2}{*}{$70 / 3$} & M.A. & 10 & 8.50 & \multirow{2}{*}{ Diploma } & \multirow{2}{*}{10} & \multirow{2}{*}{8.5} \\
\hline & & & & $\mathrm{PhD}$ & 2 & 1.70 & & & \\
\hline
\end{tabular}

Analysis from Kendall's correlation Test (Table 2) showed that there is a significant relation between coaching and managing experience with risk management behaviors.

Table 2. Relation between coaching and managing experience with risk management behaviors

\begin{tabular}{cccc}
\hline & Personal ID & \multicolumn{2}{c}{ Risk Management Behaviors } \\
\hline \multirow{2}{*}{1} & Coaching Experience & Correlation & $\mathrm{r}=0.185$ \\
& & meaningfulness & $0.033^{*}$ \\
2 & Managing Experience & Correlation & $\mathrm{r}=0.260$ \\
& & meaningfulness & $0.001^{* *}$ \\
\hline
\end{tabular}

\footnotetext{
* Significant level $(\mathrm{p} \leq 0.05)$
}

** Significant level $(\mathrm{p} \leq 0.01)$ 
The analysis of nonparametric Kruskal Wallis $\mathrm{H}$ test among the educational degrees (physical education, non-physical education and diploma) and degree of using risk management behaviors showed that there is a significant relation between them. It is shown in the Table 3. People educated in sports performed better than others in risk management behaviors and got 4 out of 5 scores (they often used the risk management techniques), and leaders with other educational degrees got 3 out of 5 (they sometimes utilized those techniques).

Table 3. Differences between risk management behavior and educational subject

\begin{tabular}{cccc}
\hline Subject of Study & Average Rate & Independence & Meaningfulness \\
\hline Physical Education & 71.82 & & \\
Non-physical Education & 54.85 & 2 & $0.006^{*}$ \\
Without any degree & 43.60 & & \\
\hline
\end{tabular}

*Significant level $(\mathrm{p} \leq 0.05)$

The analysis of Spearman test between educational degree and risk management behaviors $(\mathrm{p}=0.059 \& \mathrm{r}=0.526)$ showed there isn't any relation in them. It is shown in the Table 4.

Table 4. The relation between the educational level and risk management behaviors

Risk management behaviors

Educational Level

\begin{tabular}{ccc} 
Risk management behaviors & Correlation Coefficient & Meaningfulness \\
\hline Supervision & 0.033 & 0.725 \\
Medical Service & 0.019 & 0.834 \\
Facility & 0.104 & 0.262 \\
Equipment & 0.060 & 0.519 \\
Security \& Spectators controlling & 0.069 & 0.458 \\
Transportation & -0.098 & 0.289 \\
Security of Equipment & 0.029 & 0.759 \\
Employment Status \& Personnel Training & 0.065 & 0.483 \\
Risk management behavior & 0.059 & 0.526
\end{tabular}

*Significant level $(\mathrm{p} \leq 0.05)$

The analysis of Kruskal Wallsi H Test between employment status and risk management behavior showed that there isn't any relation between them $(\mathrm{p} \leq 0.120)$, But there is a significant difference between employment status and facility $(\mathrm{p} \leq 0.049)$. It is shown in the Table 5 .

Table 5. The difference between employment status and risk management behaviors

\begin{tabular}{ccc}
\hline Risk management behaviors & K Score & $\begin{array}{c}\text { Employment status } \\
\text { Meaningfulness }\end{array}$ \\
\hline Supervision & 1.403 & 0.844 \\
Medical Service & 2.295 & 0.682 \\
Facility & 9.539 & $0.039^{*}$ \\
Equipment & 6.693 & 0.153 \\
Transportation & 8.270 & 0.082 \\
Security of Equipment & 8.477 & 0.076 \\
Employment Status \& Personnel Training & 2.603 & 0.626 \\
Risk management behavior & 1.875 & 0.795 \\
\hline
\end{tabular}

Significant level $(\mathrm{P} \leq 0.05)$ 
As It is shown in the Table 6, the Spearman correlation test showed that there is no significant relation between coaching situation and the degree of utilizing risk management behaviors $(\mathrm{p} \leq 0.381 \& \mathrm{r}=0.092)$. But there is a significant relation between coaching and transportation $(\mathrm{P} \leq 0.037)$.

Table 6 . The relation between educational level and risk management behaviors

\begin{tabular}{ccc}
\hline Risk management behaviors & \multicolumn{2}{c}{ Educational Level } \\
& Correlation Coefficient & Meaningfulness \\
\hline Supervision & 0.186 & 0.077 \\
Medical Service & 0.051 & 0.633 \\
Facility & 0.037 & 0.726 \\
Equipment & 0.099 & 0.346 \\
Security \& Spectators controlling & 0.110 & 0.296 \\
Transportation & 0.218 & $0.037^{*}$ \\
Security of Equipment & 0.144 & 0.169 \\
Employment Status \& Personnel Training & 0.142 & 0.178 \\
Risk management behavior & 0.092 & 0.381 \\
\hline
\end{tabular}

* Significant level $(\mathrm{P} \leq 0.05)$

The analysis of $\mathrm{K}$ - score showed that line managers were better than staff managers in risk management, staff managers got 3 out of 5 and Line managers got 4 of 5. It is shown in the Figure 2.

\section{Score}

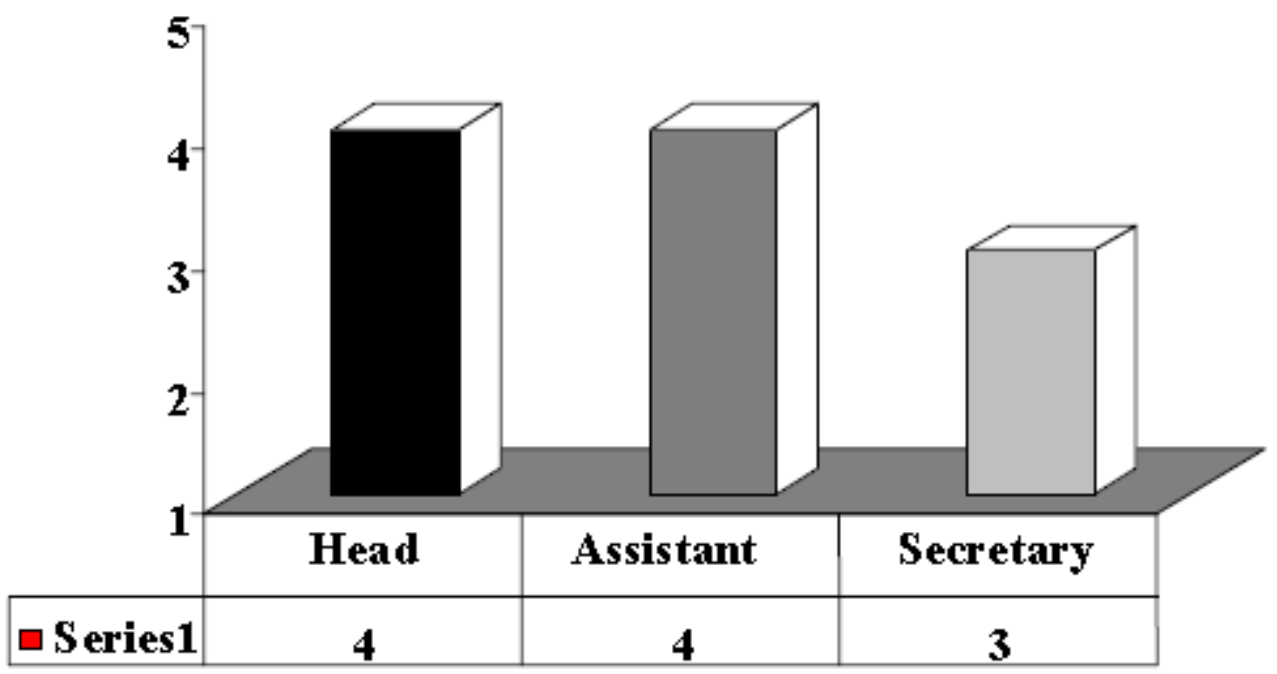

Figure 2. Comparison between line mangers and staff managers

\section{Risk Management Behaviors}

Analysis of the current research shows that managers of sports departments of Khorasan got 4 out of 5 by the Likert Scale, which means they performed risk management behaviors most of the time $(\mathrm{P} \leq 0.05)$.

\section{Conclusions}

Achieving the goals of risk management behavior depends on how risks and other factors in relation with it are evaluated and think about (Lhotsky, 2006). In this research it is shown that sport directors of Khorasan also got 4 out of 5 according to A5-Point Likert Scale, which means they tried risk management strategies most of the time.

In conclusion we can say sports councils in Khorasan are in a rather appropriate position of using risk management techniques, and between the educational levels and risk management as well. But there is no meaningful relationship between employment status and risk management behaviors. 
To achieve the goals depends on the evaluations and decisions we made in controlling and managing of risks.

Analysis of the study shows that those managers and directors with more experience in coaching had a better performance in applying risk management behaviors. They had a better idea about risks and handling them in sports through their own experience. It shows the directors who are busy with both coaching and management cannot have a good performance at risk management behaviors due to lack of time and energy (Veisi et al, 2010). So there is a significant relation between coaching experience and risk management strategies. This analysis are the same as Gray \& Crowell (1993). In their research a clear relation had been observed between coaching experience and risk management behaviors too; and managers with high level of experience were better at adapting risk management techniques.

But there haven't been much harmony between this research and those of Aeron, 2004; Lachapel, 2004; Gray \& Park, 1991; Gray \& Curtis, 1991; Gray \& Anderson, 1991 and also Gray \& Mckinstrey, 1994.

It is not reasonable to succeed in applying risk management behaviors without considering other factor and their influence as well as coaches experiences.

As it is mentioned before, there are 8 factors that should be put into attention and be connected to each other in performing risk management behaviors.

It is obvious in those research other factors are not considered as well as the coaching experience leading to different result from the study.

It is completely clear that other facts except the level of coaching experience are not well-considered in those researches (Gray \& McKinstrey, 1994; Gray \& Crowell, 1993).

Results from this research approved the hypothesis that directors with more management's experience have a better performance in risk management than those with less management's experience. And the results are in harmony with those of Aeron, 2004; Lachapel, 2004; Gray \& Park, 1991; and also Gray \& Mckinstrey, 1994.

It seems managers with degrees in physical education are better performers in risk management behaviors than those with other educational degrees.

It showed that the degrees of applying risk management behaviors are different among the manager with different educational degrees (physical education, non-physical education \& diploma). Managers with a degree in physical education are certainly better performers in risk management behaviors (Veisi et al, 2010). They got 4 out of 5 scores of Likert scale, which shows they use these techniques most of the time. And people who are not educated in physical education sometimes try risk management behaviors, 3 out of 5 .

These results are not consistent with previous research on a variety of subjects by Aeron, 2004; Gray \&Park, 1991; Gray \& Curtis, 1991; Gray \& Anderson, 1991 and also Gray \& Mckinstrey, 1994; in which no significant difference were shown when examining risk management behaviors in relation to undergraduate major.

However, in a study of Iowa high school athletic directors, Gray \& Park, 1991; found that those with sport related educational backgrounds performed higher than those athletic directors whose educational backgrounds were non-sport related. Of course there are many studies which showed there is a significant relationship between education and risk management behaviors. It seems Gray, Anderson, Curtis and others focused on other factors such as equipment and components in their researches. More researches seem to be necessary on this subject.

Although managers' knowledge in sport fields seems to have big influence on the better performance in risk management, we did not observe any significant relationship between educational degree and a better performance in risk management behaviors in the present study $(\mathrm{p} \leq 0.526 \& \mathrm{r}=0.059)$, which is in the same as with those of Aeron, 2004; Gray \&Park, 1991; Gray \& Curtis, 1991; Gray \& Anderson, 1991 and also Gray \& Mckinstrey, 1994. They also came to the conclusion that there is no significant relation between educational degree and good performance in risk management behaviors in their researches.

The point is, better education cannot be the only tool which leads them to better performance in risk management behaviors, and other factors must be considered as well. Then again more studies are needed on this matter.

It is also found that managers who are employed and work full-time had a better performance than those who work part-time. Because they are concentrated in their jobs and have much time working on risk management strategies. Statistical analysis showed that there is a significant difference between managers with different employment status such as full-time, part-time etc. This analysis is not correlated with the results of Aeron's research. More researches seem to be necessary on this subject. 
Coaching state expresses the managers' levels of coaching in their own fields.

Its relation between risk management behaviors is that managers with higher levels of skills in coaching are more successful in adapting risk management techniques, because they are more experienced and knowledgeable in their fields.

Statistical analysis from Spearman correlation test $(\mathrm{p}=0.381 \& \mathrm{r}=0.092)$ show that there isn't any significant correlation between coaching status and risk management behaviors but not in the same as the results of Aeron, 2004; Lachapel, 2002; Gray \& Park, 1991 and Appenzeler, 1998. Coaching degree is not enough for reaching the goals in risk management behaviors, and must be accompanied by coaching experience.

According to current analysis staff managers performed better than line managers in risk management behaviors ( $\mathrm{p} \leq 0.05$ ). Staff managers got 4 out of 5 from Likert Scale but line managers got 3. Line managers are executive managers who are in a direct connection with sports programs. And risk management behaviors are supposed to be their main responsibility. If they do not work on risk management as well as possible then it can bring them a lot of risks which can be hard to control them after that. The analysis also shows a weakness among line managers at performing risk management strategies which should be considered by head administrator's office.

Risk management behaviors is a new subject which needs especial qualifications which are rarely found in sports councils an organizations in Iran. It can't reach to a well performance of risk management in the organizations unless provide those qualifications. We need to have more mangers that are educated in sport fields as well as having coaching and other managing experiences in order to achieve the benefits of performing risk management behaviors. Supervision, medical Service, facility, equipment, security \& spectators controlling, transportation, security of equipment are the most important fact that should be thought about. Staff $\&$ line managers should be made more familiar with this subject.

Finally, the researcher suggest that similar research should be doing at this subject in soccer stadiums, swimming pools, athletic councils and different organizations in order to introduce risk management behaviors and adapting them in order to decrease the amount of destructions and risks in the society.

\section{References}

Aaron, T. C. (2004). Factor affecting the performance levels of risk management behaviors of Florida high school athletic directors. Published Doctoral Thesis. The Florida State University, College of Education.

Ammon, Robin., \& South all, Richard. (2005). Sport facility management. West Virginia University.

Anderson, M. A., \& Gray, G. R. (1994). Risk management behaviors in NCAA Division III Athletic programs. Journal of Legal Aspects of Sport, 4(1), 78-84.

Appenzeller, H. (Ed.). (1998). Risk management in sport: Issues and strategies. Durham, NC: Carolina Academic Press.

Arthur Williams, J. R., \& Richard Dam, Hinze. (1924). Risk management (2nd ed.). Translated by Davur, Venues., \& Hojatollah, Gudarzi. Tehran, Negahe Danesh Publisher.

Brown, D. A., \& Sawyer, T. H. (1998). Risk management study of division II athletic directors. Journal of Legal Aspects of Sport, 8(1), 24-32.

Clement, A. (1998). Law in sport and physical activity. Indianapolis, IN: Benchmark Press.

Dusti, M. (2009). Study of risk management in Iran's soccer stadiums. M.A. Dissertation, Sport Management Student, Tehran, University of Tehran.

Gray, G. R., \& Crowell, S. E. (1993). Risk management behaviors in NCAA division I athletic programs. Journal of Legal Aspects of Sport, 3(2), 64-70.

Gray, G. R., \& McKinstrey, J. P. (1994). Risk management behaviors of NCAA Division III head football coaches. Journal of Legal Aspects of Sport, 4(2), 63-71.

Gray, G. R., \&Parks, J. B. (1991). Risk management planning: Conducting a sport risk assessment to enhance program safety. Journal of Physical Education, Recreation and Dance, Research Library, 62(6), 29.

Hronek, B. B., \& Spengler, J. D. (2002). Legal liability in recreation and sports. Champaign, IL: Sagamore Publishing.

Izadi, B. (2009). Analyzing risk management behavior in public and private swimming pools in Tehran, M.A. Thesis in athletic management, Athletic College of Tarbiat Modares University, Tehran, Iran. 
Kavaler, F., \& Spiegel, A.D. (1997). Risk management in health care institutions: A Strategic approach. Sudbury, MA: Jones Bartlett.

Khoshbkhti. J., \& K, Veisi. (2009). The process of applying Ammon, Kavaler and Spengler risk management in improving volleyball in school and universities. The collection of article of The First Seminar of Volleyball Expansion in Iran, Birjand University.

Lachapelle, C. F. (2004). The risk and safety practices in youth baseball and softball. Published Doctoral Thesis. The Florida State University, College of Education.

Lhotsky, G. J. (2006). An Analysis of risk management at NCAA division I A football stadiums. Doctoral dissertation, Florida State University, College of Education, Copy right by proquest, Information and learning company.

Mulroney, A. L., \& Ammon, R. (1995). Risk management practices and the impact on insurance premiums and loss reserves. The Journal of Legal Aspects of Sport, 5(2), 57-67.

Pantera, M. J. (2003). Planning is key to locking down security. The NCAA News, 4.

Rahimi, Gh. A, Amirtash., \& M, Khabari. (2002). Study of risk management in soccer stadium from spectators, players' and executive managers' Point of View. The Journal of Research in Sport Science of Iran, 1(4), $39-52$.

Sawyer, T. H. (2002, Nov/Dec). Sports facility liability. Journal of Physical Education, Recreation \& Dance, Research Library, 73(9), 10.

Setorg Dorre Shuri, M., \& Dalvi Esfahani, M. (2005). Danesh-pahohan Javan publisher, Arkan Publisher, First Edition.

Stacey, H. (2006). Effective Security Management of University Sport Venues. Sport Journal, (4).

Veisi. K. J, Khoshbakhti. S, Mohammadi, \& M, Keshtidar. (2010). Relation between risk management behaviors and leadership styles in sport councils of southern Khorasan, M.A. Dissertation, Sport Management Student, Birjand University. 